\title{
PENGARUH KERJA SAMA ANTARA PENDIDIK DAN ORANGTUA TERHADAP PENGEMBANGAN KECERDASAN EMOSIONAL ANAK
}

\author{
THE EFFECT OF THE COOPERATION BETWEEN TEACHERS AND PARENTS \\ ON THE DEVELOPMENT OF THE EMOTIONAL INTELLIGENCE OF THE CHILDREN
}

\author{
Daning Kusniapuantari, Yoyon Suryono \\ KB Citragami Kulon Progo, Universitas Negeri Yogyakarta \\ daningkusniapuantari@yahoo.co.id, yoyonsuryono@yahoo.com
}

\begin{abstract}
Abstrak
Penelitian ini bertujuan untuk mengetahui pengaruh pengasuhan pendidik, orangtua dan kerja samanya terhadap pengembangan kecerdasan emosional anak di PPAUD Nusa Indah Bumirejo. Sampel penelitian ditentukan dengan menggunakan teknik stratified random sampling dengan besar sampel 30 anak, 30 orangtua, dan 10 pendidik. Pengumpulan data dilakukan dengan menggunakan angket, observasi, dan dokumentasi. Data dianalisis secara statistik deskriptif dan dengan metode analisis regresi linier ganda. Hasil persamaan regresi linier adalah: $\mathrm{Y}^{\prime}=-126,612+0,845 \mathrm{X}_{1}+0,864 \mathrm{X}_{2}$. Hasil ini menunjukkan bahwa pengasuhan pendidik berpengaruh signifikan terhadap kecerdasan emosional anak bila dilakukan bersama dengan orangtua. Kerja sama pengasuhan pendidik dan orangtua secara bersama-sama berpengaruh secara signifikan terhadap kecerdasan emosional anak, sumbangan pengaruhnya sebesar $73,4 \%$.
\end{abstract}

Kata kunci: kecerdasan emosi, pengasuhan pendidik, pengasuhan orangtua, kerja sama pendidik dan orangtua.

\begin{abstract}
This study aims to investigate the effect of teachers', parents, and cooperation between teachers and parents on the development of the emotional intelligence of the children in PPAUD Nusa Indah Bumirejo. The sample was selected using the stratified random sampling technique with 30 children, 30 parents and 10 teachers. The data collecting instruments consisted of a questionnaire, observation, and documentation. The data were analyzed by means of descriptive statistics and multiple regression analysis mothod. The linear regression equation is $Y^{\prime}=-126.612$ $+0.845 X_{1}+0.864 X_{2}$. This shows that teachers' upbringing has a significant effect on children's emotional intelligence if with parents simultaneously. The cooperation between teachers and parents simultaneously has a significant effect on children's emotional intelligence, the contribution of the effect is $73.4 \%$.
\end{abstract}

Keywords: emotional intelligence development, teachers' upbringing, parents' upbringing, cooperation between teachers and parent 


\section{PENDAHULUAN}

Permendiknas No 58 tahun 2009 menyebutkan bahwa lingkup perkembangan anak meliputi nilai-nilai agama dan moral, motorik, kognitif, bahasa, sosial emosional dan perkembangan anak berlangsung secara berkesinambungan yang berarti bahwa tingkat perkembangan yang dicapai pada suatu tahap diharapkan meningkat baik secara kuantitatif maupun kualitatif pada tahap selanjutnya. Setiap anak adalah unik, karena perkembangan anak berbeda satu sama lain yang dipengaruhi oleh faktor internal dan eksternal, tetapi perkembangan anak tetap mengikuti pola yang umum. Agar anak mencapai tingkat perkembangan yang optimal dibutuhkan keterlibatan orangtua dan orang dewasa untuk memberikan rangsangan yang bersifat menyeluruh dan terpadu yang meliputi pendidikan, pengasuhan, kesehatan, gizi dan perlindungan yang diberikan secara konsisten melalui pembiasaan.

Peran seorang guru atau pendidik sangat dibutuhkan untuk perkembangan anak usia dini. Pengasuhan saling memengaruhi seperti pelukan, getaran, cara mengemong dan menggendong adalah untuk kebutuhan perkembangan fisik dan psikologis anak. Kontak fisik melalui bermain, memberikan perhatian dan pengajaran adalah penting dilakukan oleh guru dalam mendorong perkembangan fisik, kesehatan, emosional dan kasih sayang. Baik orangtua maupun guru selalu berharap agar anak atau anak didiknya mampu mencapai prestasi dan tumbuh kembang secara optimal. Walaupun demikian pada kenyataannya tidak mudah menjalin kerja sama antara pendidik dan orangtua. Menurut penelitian Epstein \& Dauber (Patmonodewo, 2003, p.130) menunjukkan bahwa apabila orangtua tidak dilibatkan dalam pendidikan anak, maka perbedaan latar belakang pendidikan dan kelas sosial orangtua akan berpengaruh, tetapi bila sekolah selalu melibatkan para orangtua secara sungguh-sungguh dan melibatkan semua orangtua murid maka latar belakang tingkat pendidikan dan latar belakang kelas sosial akan makin berkurang pengaruhnya bahkan tidak tampak.

Baik orangtua maupun guru seringkali tidak memiliki pandangan yang sama terhadap pendidikan, khususnya dalam disiplin, hubungan antara anak dan orang dewasa, anak laki dan perempuan atau budayanya. Ada alasan yang kuat mengapa para guru/pendidik selalu menginginkan para orangtua melibatkan diri dalam pendidikan anak mereka. Keterlibatan orangtua di sekolah akan meringankan guru dalam membina kepercayaan diri anak, mengurangi masalah disiplin murid dan meningkatkan motivasi anak. Para guru yang menganggap orangtua sebagai pasangan atau rekan kerja yang penting dalam pendidikan prasekolah, akan makin menghargai dan makin terbuka terhadap kesediaan kerja sama orangtua.

Berdasarkan observasi awal, di PPAUD Nusa Indah Bumirejo, dapat di katakan bahwa para orangtua masih belum semuanya mempraktikkan pengasuhan anak sesuai tahap perkembangannya, selain itu juga masih kurang pengetahuannya dalam hal pola asuh anak sesuai dengan tahap perkembangan anak, karena dalam mengasuh anak-anaknya terutama pada saat pendampingan di PAUD, masing-masing orangtua punya cara dan gaya pengasuhan yang berbeda-beda. Ada yang mendampingi dengan sabar, tidak peduli, emosi/marah pada anak, selalu melindungi anak. Tentunya hal ini akan mempengaruhi kecerdasan anak terutama kecerdasan emosinya.

Melihat catatan penilaian anak yang dilakukan oleh pendidik di PPAUD Nusa Indah Bumirejo, kecerdasan emosional anak masih harus dikembangkan lagi dikarenakan masih ada sekitar 50\% anak usia 3-4 tahun yang selalu bersama orangtuanya saat bermain dan pembelajaran (penghitungan persentase diperoleh dengan cara menghitung jumlah anak yang dikategorikan masih selalu bersama orangtuanya perjumlah semua anak yang ada, di kalikan 100\%), masih ada sekitar 30\% anak yang selalu mendorong ataupun memukul teman saat bermain. Para pendidik di PPAUD Nusa Indah Bumirejo membimbing dan selalu memberi contoh yang baik pada anak, 
namun masih perlu ditingkatkan pengetahuan dalam melakukan tugas-tugasnya sebagai pendidik.

Fakta yang terjadi di PPAUD Nusa Indah Bumirejo juga menunjukkan bahwa hubungan kerja sama antara pendidik dan orangtua walaupun sudah terjalin dalam bentuk komunikasi langsung tetapi masih belum optimal. Terbukti bahwa sejak dimulainya program PAUD sampai saat berakhir masa program belum ada pertemuan khusus secara rutin ataupun semacam buku penghubung antara pendidik dan orangtua yang tentunya bermanfaat untuk mengkomunikasikan dan memantau tumbuh kembang anak sesuai tahapan perkembangan anak sehingga ada kecocokan antara pengasuhan yang dilakukan di rumah oleh orangtua dan pengasuhan oleh pendidik di PAUD. Apabila ada kecocokan atau pembiasaan yang sama antara pengasuhan oleh orangtua dan oleh pendidik maka hal ini dapat membantu dalam pengembangan kecerdasan emosional anak.

Berkaitan dengan potensi kecerdasan emosi (EQ), EQ menentukan 80\% kesuksesan, sementara IQ hanya $20 \%$. Orangtua maupun pendidik sama-sama berharap agar anak mampu mencapai prestasi dan tumbuh kembang secara optimal serta sukses di kemudian hari. Maka sangatlah penting untuk mendidik anak dengan menstimulasi kecerdasan emosi (EQ) sejak dini. Peran pengasuhan orangtua sangat di butuhkan demikian juga pendidik, jadi untuk mengembangkan kecerdasan emosional anak, orangtua anak harus menjalin kerja sama yang baik dengan pendidik. Pendidik harus mampu memfasilitasi aktivitas anak dengan materi beragam, karena seorang anak membutuhkan lingkungan yang kondusif untuk tumbuh dan berkembang dengan baik.

Pada masa lampau, emosi biasanya diabaikan dalam studi mengenai perkembangan anak. Tetapi sekarang emosi merupakan konseptualisasi yang semakin penting dalam perkembangan. Bahkan bayi-bayi menunjukkan gaya emosional yang berbeda, memperlihatkan temperamen yang berbeda, dan juga membentuk ikatan emosional terhadap pengasuhnya. Studi mengenai emosi saat ini tidak dapat mengesampingkan peran dari Daniel Goleman. Melalui bukunya Emotional Intellegence Goleman (2000, p.44) mencoba menyatakan bahwa unsur emosi merupakan faktor yang turut berperan dalam keberhasilan hidup seseorang.

Permasalahan kecerdasan emosional di PPAUD Nusa Indah saat ini perlu ditingkatkan. Ada sebagian keluarga (orangtua) yang kesulitan menghadapi sikap dan perilaku anak. Disisi lain ada kecenderungan pada saat ini yang secara perlahan-lahan tetapi pasti telah terjadi erosi terhadap fungsi keluarga. Beberapa keluarga memiliki waktu yang semakin sedikit untuk anak. Disisi lain terbentuknya sikap keluarga yang tidak peduli terhadap kebutuhan tumbuh kembang anak.

Kehidupan anak pertama kali berlangsung bersama keluarga. Tidak ada yang menyangkal bahwa orangtua adalah pendidik pertama bagi anak-anaknya. Apabila anak telah masuk sekolah, orangtua adalah mitra kerja yang utama bagi pendidik. Anak hidup dalam keluarga, bersama ayah, ibu dan anggota keluarga yang lain. Seperti diutarakan oleh berbagai ahli pendidik seperti Rousseau, Froebel dan Ki Hajar Dewantara, bahwa pada masa anak, anak sangat dekat dengan lingkungan, baik lingkungan fisik maupun lingkungan manusia. Orang-orang yang berada di sekitar anak, baik orangtua dan orang dewasa yang lain sangat berperan dalam pembentukan perilaku anak.

Kecerdasan emosional sangat diperlukan untuk menanggulangi tumbuhnya sifat mementingkan diri sendiri, mengutamakan tindak kekerasan dan sifat-sifat jahat yang lainnya (Zuchdi, 2008, p.112). Pada prinsipnya anak perlu diasuh memiliki kecerdasan emosional dikarenakan: Anak tidak memiliki taraf kecerdasan yang sudah terbentuk dan tidak juga memiliki tempo perkembangan yang tidak bisa diubah. Lingkungan dapat meningkatkan ataupun menurunkan taraf kecerdasan anak terutama pada masa-masa permulaan hidupnya, rangsangan di masa kecil bisa mengubah ukuran dan fungsi kimiawi dari otak, faktor keturunan menentukan batas tertinggi bagi taraf kecerdasan anak. Tetapi batas ini demikian tingginya sehingga tidak seorang- 
pun manusia pernah mencapainya, perubahan-perubahan dalam kemampuan mental paling besar terjadi pada saat dimana otak mengalami pertumbuhan yang paling besar. Padahal pertumbuhan otak semakin menurun dengan bertambahnya umur, dari bayi sampai umur 4 tahun anak telah mencapai separoh dari kemampuan kecerdasannya dan umur 8 tahun ia mencapai 80\%. (Yulsyofriend, 2003, p.74).

Serangkaian studi selama 30 tahun terutama di Amerika Serikat telah menunjukkan bahwa program pembinaan anak usia dini dapat memperbaiki prestasi belajar, meningkatkan produktivitas kerja dan penghasilan dimasa depannya, serta mengurangi ketergantungannya kepada pelayanan kesehatan dan sosial. Selanjutnya ditemukan bahwa yang menentukan kualitas manusia yang perlu dibina sejak dini selain emosi anak adalah kesehatan, nutrisi dan stimulasi intelektual. Ketiga hal tersebut perlu ditangani secara serentak dan sinergik. Maksudnya tidak dapat mengutamakan hanya salah satu dimensi saja

Berdasarkan kondisi yang ada di PPAUD Nusa Indah mengenai kecerdasan emosional anak tersebut peneliti melihat perlu adanya penelitian lebih lanjut untuk mengetahui dan memperoleh informasi tentang pengaruh kerja sama antara pendidik dan orangtua terhadap kecerdasan emosional anak di PPAUD Nusa Indah Bumirejo. Diharapkan dari hasil penelitian ini dapat menjadi masukan untuk para pendidik PAUD khususnya di PPAUD Nusa Indah Bumirejo dan para orangtua anak dalam mengembangan kecerdasan emosi anak.

Dari hasil observasi awal tersebut dapat dikatakan bahwa kecerdasan emosional anak di PPAUD Nusa Indah Bumirejo masih rendah dan sangat perlu untuk dikembangkan. Secara lebih terinci, permasalahan penelitian ini adalah sebagai berikut: Apakah terdapat pengaruh pengasuhan pendidik terhadap pengembangan kecerdasan emosi anak?, Apakah terdapat pengaruh pengasuhan orangtua terhadap pengembangan kecerdasan emosi anak?, Apakah terdapat pengaruh kerja sama antara orangtua dan pendidik terhadap pengembangan kecerdasan emosi anak?

Tujuan umum penelitian ini adalah dapat memperoleh informasi yang jelas tentang permasalahan pengembangan kecerdasan emosional anak yang terjadi di PPAUD Nusa Indah Bumirejo. Adapun tujuan lebih khusus dari kegiatan penelitian ini adalah: Mengetahui pengaruh pengasuhan pendidik terhadap pengembangan kecerdasan emosional anak, Mengetahui pengaruh pengasuhan orangtua terhadap pengembangan kecerdasan emosional anak, Mengetahui pengaruh kerja sama antara pendidik dan orangtua terhadap pengembangan kecerdasan emosional anak.

Manfaat yang diperoleh dari kegiatan penelitian ini adalah : Bagi peneliti bisa mengembangkan ilmu pengetahuan dan menambah wawasan tentang pengasuhan anak (parenting), Memberikan informasi tentang pola pengasuhan kepada pendidik dan para orangtua anak sehingga dapat menambah pengetahuan dan menerapkan dalam pembelajaran serta pengasuhan anak, Memberikan masukan bagi pendidik PAUD untuk meningkatkan mutu pendidikan sehingga metode yang digunakan sesuai dengan tahap perkembangan anak, Memberikan informasi kepada masyarakat tentang pentingnya mengikutsertakan anak dalam program PAUD untuk merangsang perkembangan emosional anak.

\section{METODE}

\section{Jenis Penelitian}

Penelitian ini menggunakan pendekatan kuantitatif dengan metode expost facto yang berarti tidak ada perlakuan terhadap variabel penelitian. Penelitian menggunakan tiga variabel yaitu kecerdasan emosional anak, pengasuhan pendidik dan pengasuhan orangtua.

\section{Waktu dan Tempat Penelitian}

Penelitian dilakukan di PPAUD Nusa Indah Bumirejo Lendah Kulon Progo Yogyakarta. Penelitian dilakukan dari bulan Januari sampai September 2013. 


\section{Populasi dan Sampel Penelitian}

Populasi dalam penelitian ini adalah anak, pendidik dan orangtua di PPAUD Nusa Indah Bumirejo pada tahun akhir program (tahun 2011/2012). Pengambilan sampel yang dilakukan menggunakan teknik stratified random sampling. Pertama kali ditetapkan area yaitu TPK PPAUD Nusa Indah I dan TPK PPAUD Nusa Indah II. Masing-masing TPK ada 7 pos PAUD. Masing-masing TPK diambil sampel berdasar area yang mudah dijangkau dan jumlah anak relatif lebih banyak. Untuk TPK Nusa Indah I sampelnya adalah pos PAUD tempel, Senik, sedangkan TPK Nusa Indah II terpilih sampelnya adalah Paud Pusat Dukuh, pos PAUD Gegunung, Cabean.

Dari masing-masing pos PAUD yang terpilih diambil sampel berdasarkan usia anak 3-4 tahun dan selanjutnya masingmasing pos PAUD yang ada anak usia 3-4 tahun tersebut di ambil sampel berdasar kategori kesehatan/nutrisi dengan hasil timbangan selalu naik dan tetap dan atau turun, kemudian dikategorikan dengan penilaian baik, sedang dan rendah. Masingmasing kategori diambil sampel 2 anak, sehingga diperoleh sampel 30 anak. Sampel orangtua sesuai dengan jumlah anak 30 orangtua. Sampel pendidik sesuai pos PAUD yang terpilih dari 5 pos PAUD masingmasing 2 pendidik yang dianggap lebih berpengalaman di pos PAUD tersebut, jadi jumlah sampel pendidik ada 10 orang.

\section{Teknik Pengumpulan Data}

Data yang diperlukan dalam penelitian ini adalah data variabel pengasuhan pendidik, pengasuhan orangtua, dan kecerdasan emosional anak. Pengumpulan data pada penelitian ini menggunakan angket yang ditujukan pada responden pendidik dan orangtua, sedangkan untuk memeroleh data kecerdasan anak yaitu observasi dan dokumentasi.

Penyusunan instrumen didasarkan pada kisi-kisi yang merupakan kajian dari beberapa teori yang relevan dengan variabel penelitian.

\section{Alat Pengumpul Data}

Pada penelitian ini pengumpulan data menggunakan jenis metode Angket (Questionnaire), Observasi dan dokumentasi.

\section{Teknik Analisis Data}

Data dikumpulkan melalui angket yang ditujukan pada pendidik dan orangtua, sedangkan data variabel anak diperoleh melalui observasi (cheklist). Instrumen penelitian yang digunakan adalah kuesioner yang berupa daftar pertanyaan tertutup. Kuesioner tersebut terdiri atas dua bagian yaitu: Kuesioner pendahuluan untuk mengetahui karakteristik responden yang meliputi nama, jenis kelamin, usia, tingkat pendidikan, pekerjaan, pendapatan per bulan, pelatihan yang pernah diikuti, dan kuesioner mengenai variabel-variabel penelitian yang akan diteliti menurut indikatorindikator pengasuhan pendidik, pengasuhan orangtua dan kecerdasan emosional anak dengan skala Likert.

Data dianalisis dengan menggunakan statistik deskriptif dan regresi linier. Agar hasil analisis data benar-benar memiliki tingkat keterpercayaan yang tinggi maka perlu dilakukan uji persyaratan analisis meliputi uji normalitas, uji multikolinearitas, uji heteroskedastisitas. Selanjutnya dilakukan analisis regresi linier dan uji hipotesis yaitu uji F dan uji t.

\section{HASIL PENELITIAN DAN PEMBAHASAN}

Berdasarkan Kuesioner mengenai variabel-variabel penelitian yang akan diteliti menurut indikator-indikator pengasuhan pendidik, pengasuhan orangtua dan kecerdasan emosional anak diperoleh hasil yang meliputi (a) mengenali emosi (b) mengelola emosi (c) memotivasi diri (d) mengenal emosi orang lain/empati (e) membina hubungan dengan orang lain.

\section{Mengenali Emosi}

Berikut ini adalah grafik persentase mengenali emosi dan rata-rata mengenali emosi menurut penilaian pendidik (berdasar pengasuhan pendidik), penilaian orangtua, dan hasil observasi secara cheklist 
terhadap anak dengan kategori kesehatan/ nutrisi baik, sedang dan rendah.

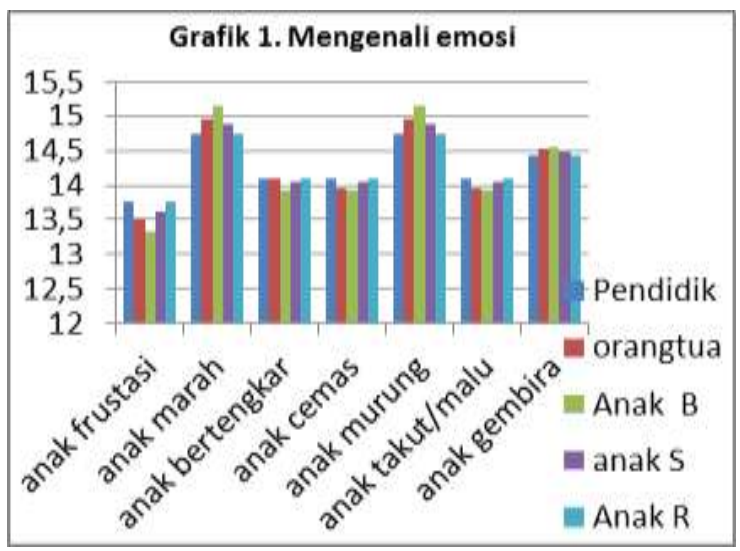

Gambar 1. Grafik Hasil Persentase Mengenali Emosi

Gambar 1 menunjukkan bahwa persentase mengenali emosi yang persentasenya tinggi adalah anak marah dan murung dan yang rendah adalah anak frustasi. Ini menunjukkan bahwa di PPAUD Nusa Indah Bumirejo anak yang menunjukkan ekspresi marah dan murung lebih tinggi daripada anak yang frustasi. Sedangkan rata-rata persentase mengenali emosi pada gambar 2.

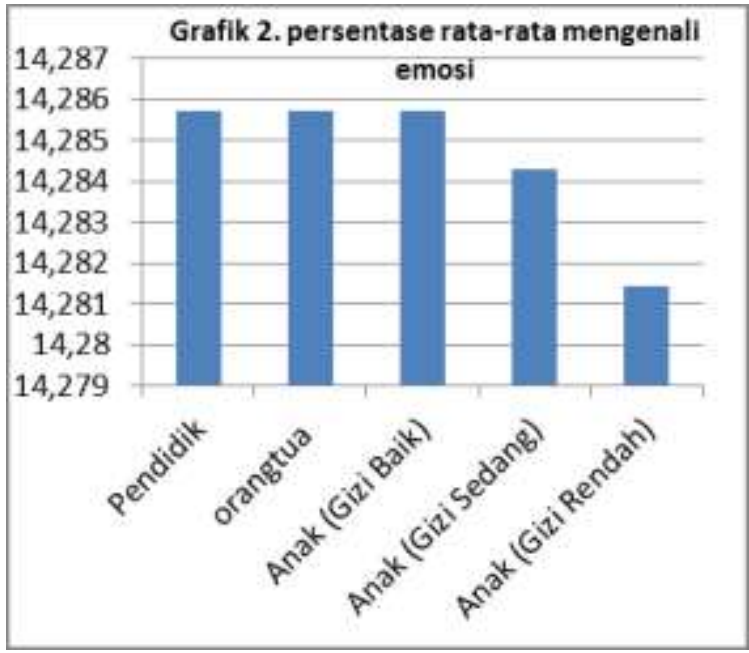

Gambar 2. Grafik Persentase Rata-rata Mengenali Emosi

Untuk mengetahui anak yang mam$\mathrm{pu} /$ bisa mengenali emosi, pada penelitian ini dilakukan penilaian tentang anak yang bisa menunjukkan ekspresi frustasi, marah, bertengkar, cemas, murung, takut/malu, dan gembira. Dari hasil yang ditunjukkan oleh grafik pada Gambar 1 dan 2 tersebut dapat dijelaskan bahwa persentase anak yang mampu mengenali emosi yang terjadi di PPAUD Nusa Indah masih pada kategori sangat rendah yaitu berkisar $14 \%$ (di bawah $25 \%)$.

Sesuai pada grafik pada Gambar 1 dan 2 dapat dijelaskan bahwa penilaian oleh pendidik dan orangtua terhadap ekspresi anak yang ditunjukkan dalam hal mengenali emosi adalah sama besarnya dan berdasar observasi menurut faktor kesehatan/nutrisi anak dengan kategori baik maka hasilnya lebih tinggi dibandingkan dengan kategori kesehatan anak yang sedang dan yang rendah. Hal ini berarti bahwa nutrisi/kesehatan anak semakin rendah maka persentase anak mampu mengenali emosinya semakin rendah.

\section{Mengelola Emosi}

Berikut ini adalah grafik persentase mengelola emosi dan rata-rata mengelola emosi menurut penilaian pendidik (berdasar pengasuhan pendidik), penilaian orangtua, dan hasil observasi secara cheklist terhadap anak dengan kategori kesehatan/nutrisi baik, sedang dan rendah.

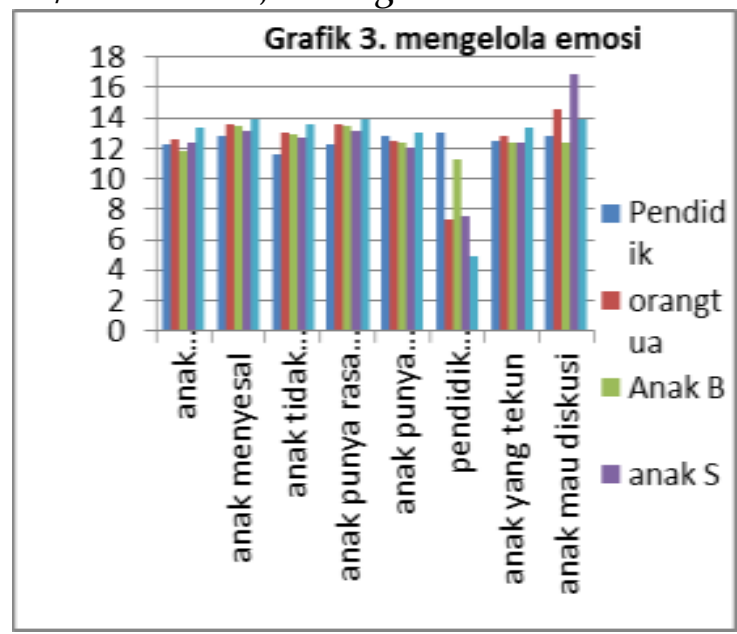

\section{Gambar 3. Grafik Hasil Persentase Mengelola Emosi}

Dari Gambar 3 dapat dilihat bahwa persentase mengelola emosi yang persentasenya tinggi adalah anak mau diajak diskusi dan yang rendah adalah pendidik masih kurang dalam mengajarkan ketekunan. Ini menunjukkan bahwa di PPAUD Nusa Indah Bumirejo anak yang menunjukkan anak di PPAUD Nusa Indah mau diajak diskusi dengan baik dan pendidik masih perlu meningkatkan dalam mengajar- 
kan ketekunan. Hal ini terjadi karena pendidik sebagian besar masih kurang sabar dalam mengajarkan ketekunan sehingga masih sering membantu dalam segala kegiatan anak. Sedangkan rata-rata persentase mengelola emosi pada Gambar 4.

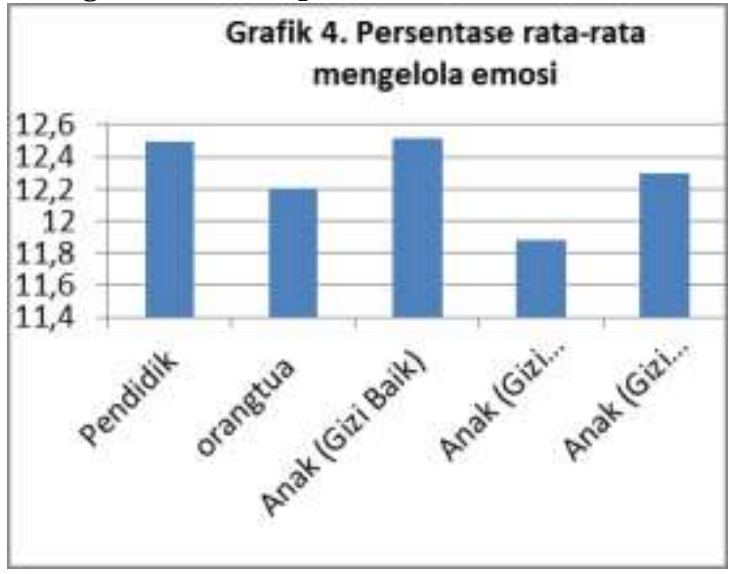

Gambar 4. Grafik Persentase Rata-rata Mengelola Emosi

Sesuai grafik pada Gambar 3 dan 4 dapat diartikan bahwa keterampilan anak mengelola emosi yang dinilai antara lain anak bisa mengendalikan emosi, menyesal atas kesalahannya, tidak mudah putus asa, mempunyai rasa percaya diri, punya optimisme, tekun dan mau diskusi. Dari penilaian yang dilakukan oleh pendidik dan orangtua dapat dijelaskan bahwa kemampuan anak mengelola emosinya masih sangat rendah yaitu berkisar $11-12 \%$ (di bawah $25 \%$ ).

Sedangkan dari hasil observasi yang dilakukan ditunjukkan bahwa ketrampilan anak dalam mengelola emosi dengan kategori nutrisi/kesehatan anak baik, sedang dan rendah adalah sama. Hal ini menujukkan bahwa faktor nutrisi/kesehatan anak tidak mempengaruhi ketrampilan anak dalam mengelola emosinya.

\section{Memotivasi Diri}

Berikut ini adalah grafik persentase memotivasi diri dan rata-rata memotivasi diri menurut penilaian pendidik (berdasar pengasuhan pendidik), penilaian orangtua dan hasil observasi secara cheklist terhadap anak dengan kategori kesehatan/nutrisi baik, sedang dan rendah.

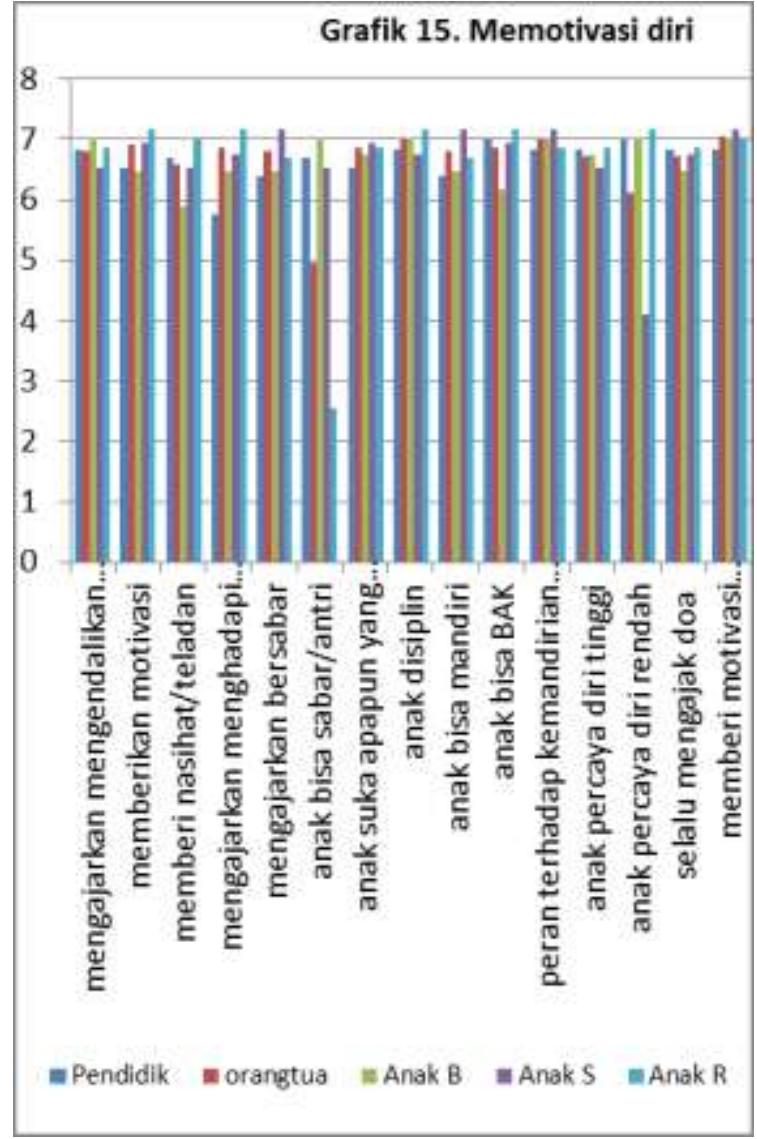

Gambar 5. Grafik Hasil Persentase Memotivasi Diri

Dari Gambar 5 dapat dilihat bahwa persentase memotivasi diri rata-rata adalah sama tinggi dan yang rendah adalah anak bisa antri. Ini menunjukkan bahwa di PPAUD Nusa Indah Bumirejo masih banyak anak yang belum bisa antri. Sedangkan ratarata persentase mengenali emosi pada gambar 6.

Hasil yang ditunjukkan sesuai grafik pada Gambar 5 dan 6 dapat dijelaskan bahwa penilaian yang dilakukan oleh pendidik dan orangtua tentang keterampilan anak dalam memotivasi diri antara lain anak bisa bersabar/antri, disiplin, bisa BAK, mendengarkan nasehat, mau berdoa, suka dengan apapun kegiatannya. 


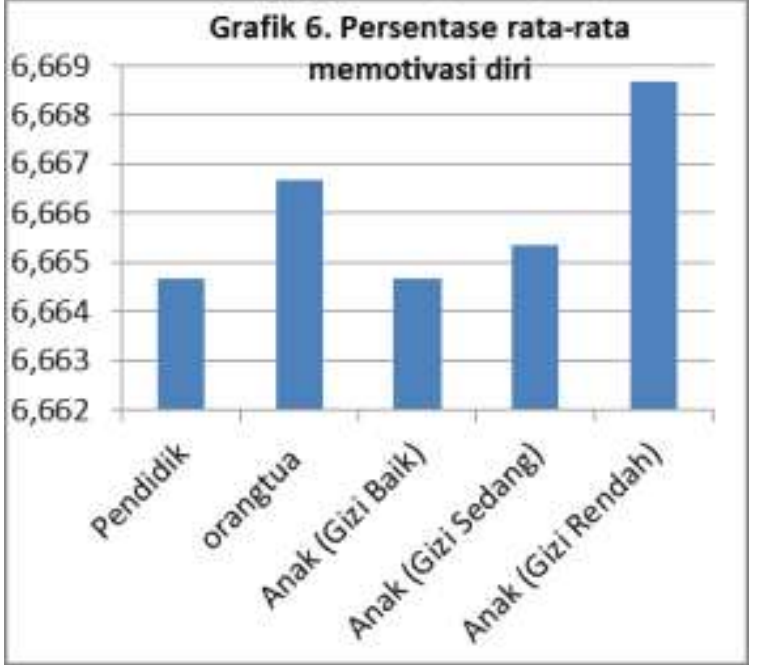

Gambar 6. Grafik Persentase Rata-rata Memotivasi Diri

Dari penilaian pendidik dan orangtua diperoleh hasil persentase anak yang mempunyai ketrampilan memotivasi diri masih sangat rendah yaitu berkisar 6\% (di bawah 25\%). Sedangkan menurut hasil observasi yang dilakukan terhadap anak dengan kategori nutrisi/kesehatan baik maka diperoleh persentase anak mempunyai keterampilan memotivasi diri lebih rendah dibanding dengan nutrisi/kesehatan anak yang sedang dan rendah. Hal ini menujukkan bahwa semakin rendah nutrisi/kesehatan anak maka keterampilan anak memotivasi diri akan semakin baik.

\section{Mengenal Emosi Orang Lain/Empati}

Berikut ini adalah grafik persentase mengenal emosi orang lain/empati dan ratarata mengenal emosi orang lain/empati menurut penilaian pendidik (berdasar pengasuhan pendidik), penilaian orangtua dan hasil observasi secara cheklist terhadap anak dengan kategori kesehatan/nutrisi baik, sedang dan rendah.

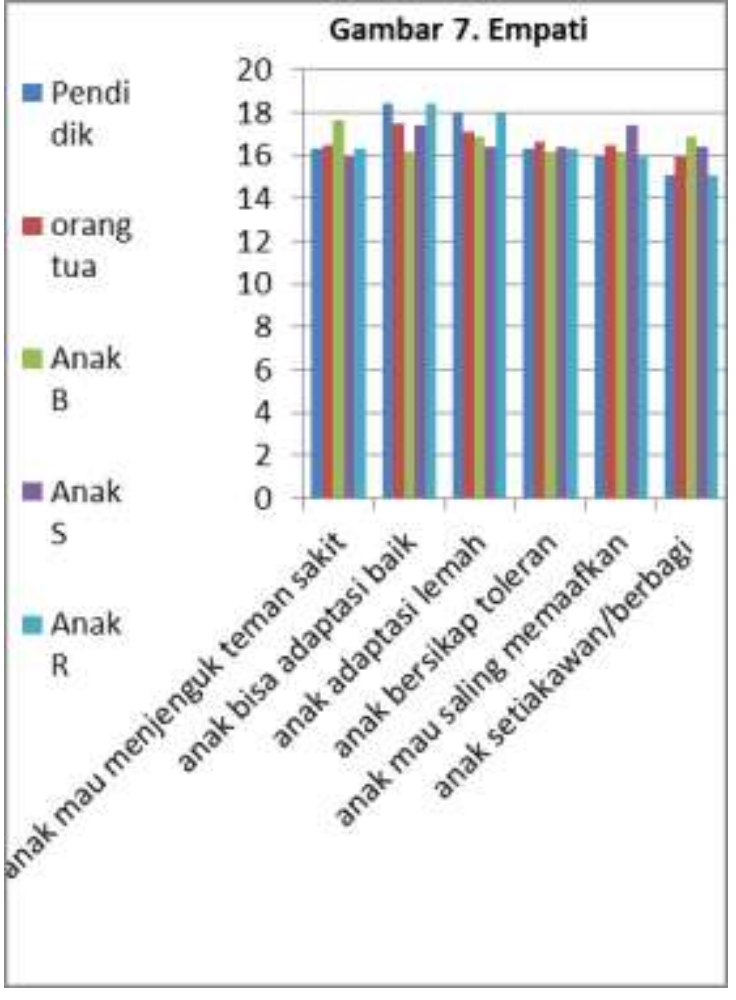

Gambar 7. Grafik Hasil Persentase Empati

Dari Gambar 7 dapat dilihat bahwa persentase empati rata-rata persentasenya tinggi. Persentase yang lebih rendah terlihat pada anak bisa adaptasi dengan baik dan anak mau berbagi/setiakawan. Ini menunjukkan bahwa di PPAUD Nusa Indah Bumi rejo masih ada anak yang belum bisa beradaptasi dengan baik dan masih kurang dalam hal setiakawan. Sedangkan persentase rata-rata empati sebagaimana pada gambar 8.

Hasil yang ditunjukkan sesuai grafik pada 7 dan 8 dapat dijelaskan bahwa penilaian yang dilakukan oleh pendidik dan orangtua tentang keterampilan anak dalam mengenal emosi orang lain/empati antara lain anak bisa menunjukkan sikap toleran, setiakawan/berbagi, mau menjenguk teman sakit, bisa beradaptasi dengan lingkungan, mau saling memaafkan. 


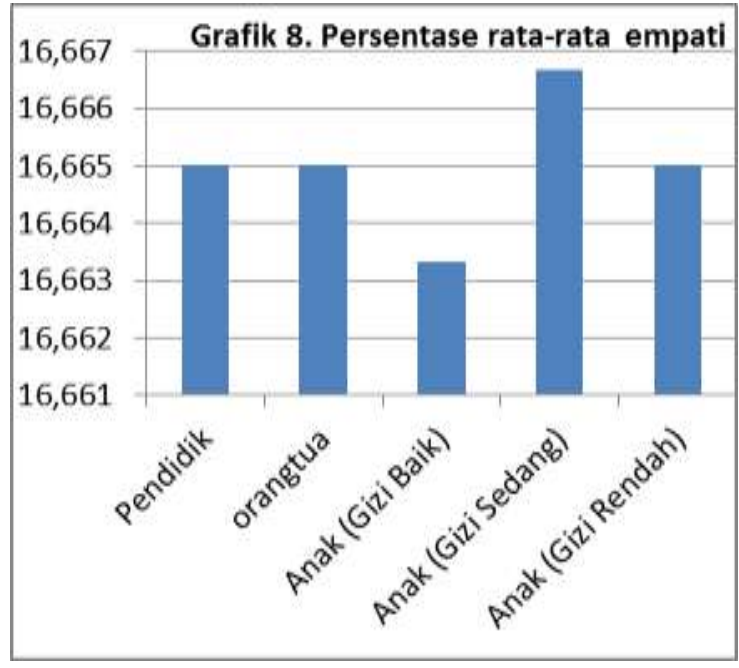

Gambar 8. Grafik Persentase Rata-rata Empati

Dari penilaian pendidik dan orangtua diperoleh hasil persentase anak yang mempunyai ketrampilan mengenal emosi orang lain/empati adalah sama yaitu masih sangat rendah (di bawah 25\%). Sedangkan menurut hasil observasi yang dilakukan terhadap anak dengan kategori nutrisi/ kesehatan baik maka diperoleh persentase anak mempunyai keterampilan mengenal emosi orang lain/empati lebih rendah dibanding dengan nutrisi/kesehatan anak yang sedang dan rendah. Anak dengan nutrisi sedang menunjukkan bahwa keterampilan berempatinya paling tinggi dibanding yang baik dan rendah. Hal ini menujukkan bahwa semakin rendah nutrisi/ kesehatan anak maka keterampilan anak berempati belum tentu akan semakin rendah.

\section{Membina Hubungan dengan Orang Lain}

Berikut ini adalah grafik persentase membina hubungan dengan orang lain dan rata-rata membina hubungan dengan orang lain menurut penilaian pendidik (berdasar pengasuhan pendidik), penilaian orangtua (berdasar pengasuhan orangtua), dan hasil observasi secara cheklist terhadap anak dengan kategori kesehatan/nutrisi baik, sedang dan rendah.

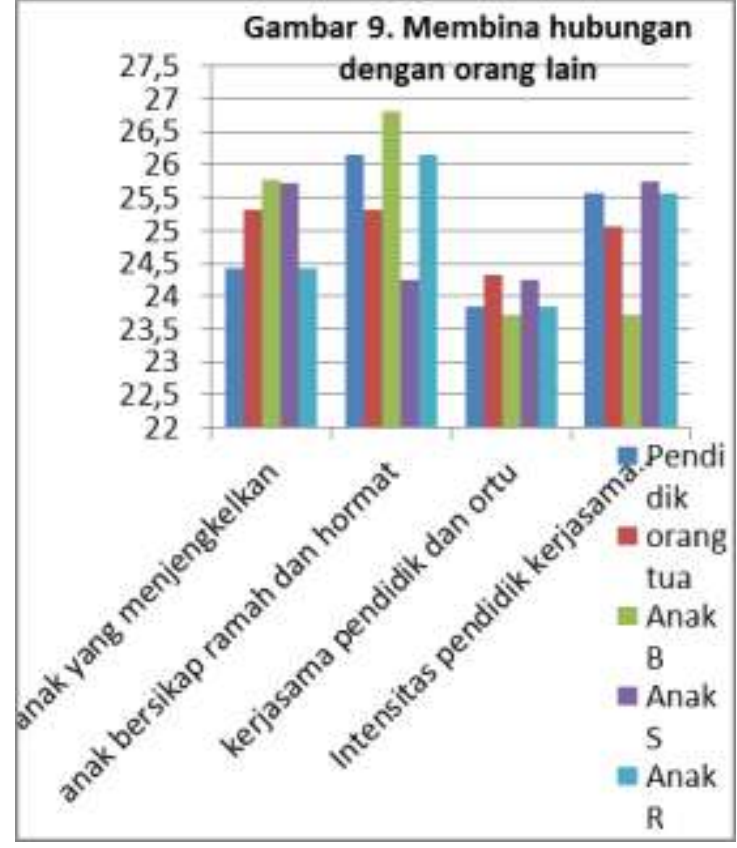

Gambar 9. Grafik Persentase Membina Hubungan dengan Orang Lain

Dari Gambar 9 dapat dilihat bahwa persentase membina hubungan dengan orang lain yang persentasenya tinggi adalah anak bersikap ramah dan hormat dan yang rendah adalah kerja sama pendidik dan orangtua. Ini menunjukkan bahwa di PPAUD Nusa Indah Bumirejo anak didiknya bersikap ramah dan hormat, namun kerja sama antara pendidik dan orangtua masih rendah. Persentase rata-rata membina hubungan dengan orang lain adalah sebagaimana pada gambar 10.

Hasil yang ditunjukkan sesuai grafik pada Gambar 9 dan 10 dapat dijelaskan bahwa penilaian yang dilakukan oleh pendidik dan orangtua tentang keterampilan anak dalam membina hubungan dengan orang lain/bersosialisasi antara lain anak bisa bersikap ramah dan hormat, anak bisa bersosialisasi dengan baik/tidak menjengkelkan. 


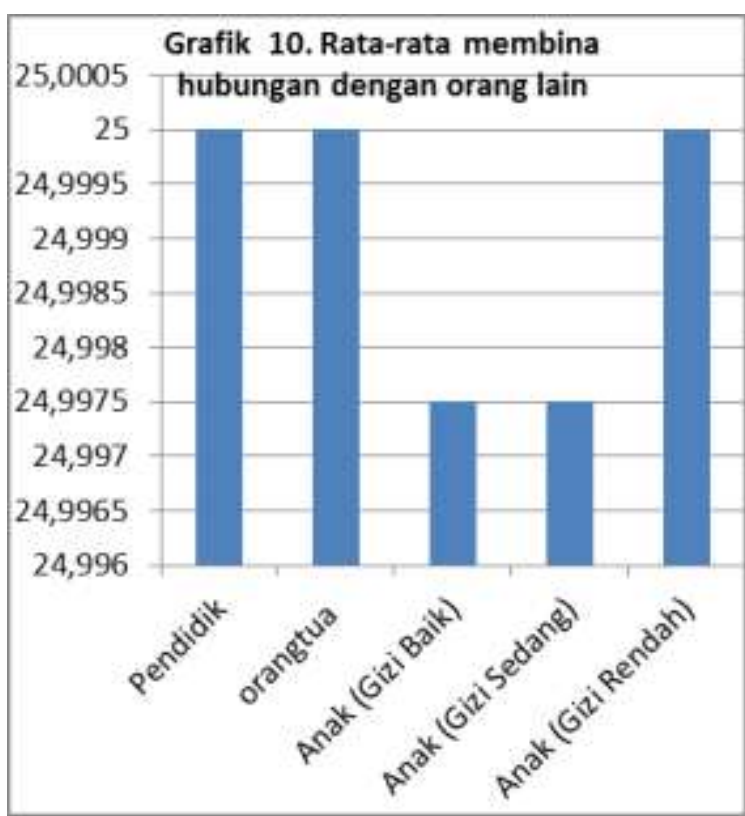

Gambar 10. Grafik Persentase Rata-rata Membina Hubungan dengan Orang Lain

Dari penilaian pendidik dan orangtua diperoleh hasil persentase anak yang mempunyai keterampilan membina hubungan dengan orang lain masih rendah. Sedangkan menurut hasil observasi yang dilakukan terhadap anak dengan kategori nutrisi/kesehatan baik maka diperoleh persentase anak mempunyai keterampilan membina hubungan dengan orang lain sama dengan kategori nutrisi sedang dan lebih rendah dibanding dengan kategori kesehatan/nutrisi rendah. Hal ini menunjukkan bahwa semakin rendah nutrisi/kesehatan anak maka keterampilan anak membina hubungan dengan orang lain akan semakin baik.

Pengembangan kecerdasan emosional anak yang diteliti ada lima aspek yaitu mengenali emosi, mengelola emosi, memotivasi diri, mengenali emosi orang lain/ empati, membina hubungan dengan orang lain. Lima aspek ini merupakan hal yang dilakukan pendidik dan orangtua dalam mengasuh anak untuk menstimulasi kecerdasan emosionalnya.

Berdasar hasil penelitian ini menunjukkan bahwa pengembangan kecerdasan emosi anak di PPAUD Nusa Indah Bumirejo tidak dipengaruhi oleh pengasuhan yang hanya dilakukan oleh pendidik saja namun pengasuhan yang hanya dilakukan oleh orangtua berpengaruh terhadap kecerdasan emosional anak. Hal ini ditunjukkan dari hasil statistik pengujian secara sendiri-sendiri (uji t) diperoleh nilai signifikansi pengasuhan pendidik sebesar o,o98. Nilai ini lebih besar dari o,05 sehingga pengasuhan pendidik tidak berpengaruh terhadap kecerdasan emosi anak. Nilai signifikansi pengasuhan orangtua sebesar o,ooo lebih kecil dari o,05. Ini menunjukkan bahwa pengasuhan orangtua berpengaruh terhadap kecerdasan emosi anak.

Hasil tersebut menunjukkan bahwa pengembangan kecerdasan emosi anak tidak bisa hanya dilakukan oleh pendidik saja, tetapi bisa dilakukan oleh orangtua saja. Hal ini bisa terjadi di PPAUD Nusa Indah Bumirejo dikarenakan frekuensi pertemuan antara pendidik dan anak hanya berlangsung 3 hari dalam seminggu, setiap pertemuan hanya terbatas 2 jam. Efektifnya dalam satu minggu pendidik mengasuh anak selama 6 jam saja. Selebihnya pengasuhan dilakukan oleh orangtua. Sehingga secara logika pengasuhan oleh pendidik tidak bisa optimal sebagaimana yang dilakukan oleh orangtua anak.

Sesuai teori Pestalozzi yang secara garis besarnya mengemukakan pentingnya lingkungan keluarga terhadap pendidikan anak usia dini karena keluarga merupakan kunci keberhasilan pendidikan. Orangtua adalah guru pertama bagi anak-anak, peran orangtua adalah membimbing dan mengarahkan anak-anaknya untuk melakukan penjelajahan dan pembelajaran dari seluruh media belajar.

Oleh sebab itu hendaknya orangtua menjaga anak-anaknya agar mereka selalu dalam kebaikan, mendidik dan mengajarkan kesederhanaan dan adab mulia, menjauhkannya dari pergaulan yang buruk, serta tidak menanamkan cinta kemewahan pada diri anak, menghargai emosi-emosi negatif anak sebagai sebuah kesempatan untuk semakin akrab, sabar menghabiskan waktu dengan seorang anak yang sedih, marah, atau ketakutan, tidak menjadi berang menghadapi emosi itu, sadar dan menghargai emosi-emosinya sendiri, melihat dunia emosi negatif sebagai arena yang penting dalam mengasuh anak, peka terhadap keadaan emosional anak, bahkan bila keadaan 
emosionalnya itu tidak terlalu kelihatan, tidak bingung atau cemas menghadapi ungkapan-ungkapan emosional anak, mengetahui apa yang perlu dilakukan, menghormati emosi-emosi anak, tidak menganggap lucu atau meremehkan perasaan negatif anak, tidak memerintahkan apa yang harus dirasakan oleh anak, tidak merasa bahwa ia harus membereskan segala masalah bagi anak, menggunakan saat-saat emosional sebagai saat untuk mendengarkan anak, berempati dengan kata-kata yang menyejukkan dan kemesraan, menolong anak memberi nama emosi yang sedang dirasakannya, menawarkan petunjuk tentang mengatur emosi, menentukan batas-batas dan mengajar ungkapan-ungkapan emosi yang dapat diterima, mengajarkan keterampilan-keterampilan untuk menyelesaikan masalah, yang semua itu dapat dikatakan bahwa menjadi orangtua hendaknya bisa menjadi orangtua pelatih emosi.

Pengembangan kecerdasan emosional anak di PPAUD Nusa Indah Bumirejo juga dipengaruhi oleh pengasuhan yang dilakukan secara bersama-sama antara pendidik dan orangtua atau ada kerja sama antara pendidik dan orangtua dalam hal kecocokan mengasuh anak untuk menstimulasi kecerdasan emosinya. Hal ini ditunjukkan dari hasil Uji $F$ yang diperoleh nilai signifikansi sebesar o,ooo.

Berdasar analisis regresi ditemukan sifat hubungan linier dengan hasil persamaan linier berganda sebagai berikut:

$Y^{\prime}=-126,612+0,845 X_{1}+0,864 X_{2}$

Hasil ini menunjukkan bahwa : Jika pengasuhan pendidik, pengasuhan orangtua nilainya o, maka kecerdasan emosi anak nilainya negatif sebesar $-\mathbf{1 2 6 , 6 1 2}$. Ini berarti bahwa jika tidak ada pengasuhan yang baik dari pendidik maupun orangtua maka kecerdasan emosi anak sangat rendah, jika pengasuhan pendidik ditingkatkan sebesar 1 satuan maka kecerdasan emosi anak akan meningkat sebesar o,845. Ini berarti bahwa jika pengasuhan pendidik ditingkatkan maka kecerdasan emosi anak juga akan meningkat, jika pengasuhan orangtua ditingkatkan sebesar 1 satuan maka kecerdasan emosi anak akan meningkat sebesar o,864.
Ini berarti bahwa jika pengasuhan ibu ditingkatkan maka kecerdasan emosi anak juga akan meningkat.

Ada banyak faktor dari dalam keluarga yang mempengaruhi perkembangan anak, seperti pengaruh ibu, tingkat sosialekonomi, hubungan dengan anggota keluarga lain dan tingkat pendidikan orangtua. Keterlibatan Ibu dalam mendidik anak usia dini mempunyai pengaruh yang besar. Ibu yang tidak bekerja, dengan kata lain hanya di rumah, menunjukkan pengaruh positif terhadap perkembangan anak dibandingkan dengan ibu yang bekerja. Mereka mempunyai lebih banyak waktu untuk berkomunikasi dengan anak, sehingga menciptakan suatu lingkungan keluarga yang sehat bagi perkembangan anak. Tingkat pendidikan Ibu juga berpengaruh terhadap perkembangan anak, ibu yang memiliki intelektual tinggi cenderung mendidik anaknya dengan lebih baik dibandingkan dengan ibu yang memiliki intelektual rendah. Tingkat sosial-ekonomi dan keharmonisan hubungan dengan anggota keluarga, merupakan faktor penentu keberhasilan fungsi suatu keluarga. Keluarga yang berfungsi dengan baik, akan berdampak positif bagi perkembangan anak ke depan. Untuk itu, kualitas hubungan dalam keluarga yang terbentuk selama anak usia dini mempengaruhi perilaku dan pikiran anak di masa depan.

Berdasarkan hasil penelitian menunjukkan bahwa kecerdasan emosi anak secara signifikan dipengaruhi oleh kerja sama pengasuhan antara pendidik dan orangtua secara bersama-sama dan diperoleh $\mathrm{F}$ hitung sebesar 41,021 dan sig 0,000. Berdasar nilai signifikansi sebesar o,ooo tersebut lebih kecil dari 0,05. Hal ini berarti kedua variabel tersebut mempunyai pengaruh yang signifikan, dengan demikian dapat diartikan semakin baik kerja sama antara pendidik dan orangtua maka akan semakin baik pula pengembangan kecerdasan emosi anak. Secara keseluruhan hasil penelitian ini mendukung kerangka teoritik yang ada.

Secara statistik kerja sama pengasuhan pendidik dan orangtua secara bersama-sama memberikan sumbangan pengaruh terhadap kecerdasan emosi anak sebesar $73,4 \%$ sedangkan sisanya $26,6 \%$ 
dipengaruhi oleh faktor lain yang tidak diteliti. Dominannya faktor kerja sama antara pendidik dan orangtua dalam memberikan sumbangan pengaruh terhadap kecerdasan emosi anak maka perlu diperhatikan faktor-faktor yang mempengaruhi kerja sama antara pendidik dan orangtua secara maksimal sehingga dapat dilakukan usaha untuk meningkatkan kecerdasan emosi anak.

Sesuai dengan teori, menurut Sudjud (1998, p.103) orangtua dapat memainkan berbagai peran, yaitu orangtua sebagai pendidik, orangtua sebagai relawan, orangtua sebagai pembuat keputusan, dan orangtua sebagai anggota tim kerja sama dengan guru di sekolah. Melalui berbagai peran memungkinkan orangtua membantu pelayanan perkembangan dan pertumbuhan anak-anak mereka baik dirumah maupun disekolah.

Orangtua adalah pola anutan atau model yang selalu ditiru dan dicontoh oleh anak-anak dalam segala gerak dan perbuatannya baik secara langsung atau tidak langsung. Disamping itu anak-anak yang masih kecil pada dasarnya mempunyai sifat percaya diri yang dialami, bahkan ketika menghadapi sesuatu yang mustahil dan kegagalan yang berulangkali. Hingga usia enam atau tujuh tahun, anak-anak menaruh harapan yang tinggi untuk berhasil meskipun kinerja pada usaha-usaha yang dilakukannya hampir selalu tidak berhasil. Ciriciri utama dari anak usia dini adalah ulet, optimisme, motivasi diri, dan antusiasme. Sifat inilah yang disebut sebagai kecerdasan emosional (emotional Intelligence).

Hasil penelitian menunjukkan bahwa rata-rata persentase mengenali emosi di PPAUD Nusa Indah Bumirejo yang tinggi adalah sikap marah dan murung sedangkan yang rendah adalah frustasi. Ini berarti bahwa pengasuhan pendidik maupun orangtua anak belum optimal dalam membantu anak untuk mengenali emosi (kesadaran diri, mengenali perasaan sewaktu perasaan itu terjadi) khususnya sikap marah dan murung. Orang yang memiliki keyakinan yang lebih tentang perasaannya adalah pilot yang andal bagi kehidupan mereka, karena mempunyai kepekaan lebih tinggi akan perasaan mereka yang sesungguhnya atas pengambilan keputusan-keputusan masalah pribadi. Jadi apabila orangtua dan pendidik bisa optimal dalam menstimulasi anak sejak dini dalam hal mengenali emosi yang merupakan dasar kecerdasan emosional akan mempersiapkan kehidupannya kelak lebih baik.

Rata-rata persentase mengelola emosi yang tinggi adalah anak mau di ajak diskusi, sedangkan yang rendah adalah pendidik masih kurang dalam mengajarkan ketekunan, pendidik masih tidak sabar dalam mendampingi kegiatan anak, selalu membantu sebelum anak mencoba menyelesaikan sendiri kegiatannya. Sehingga anak mudah bosan dan tidak mau mencoba lagi. Namun anak mau diajak diskusi sehingga harapannya pendidik bisa mendiskusikan/ mengkomunikasikan untuk menstimulasi anak bisa mengelola emosinya.

Rata-rata persentase memotivasi diri hampir semua tinggi, yang rendah adalah anak bisa sabar/antri. Hal ini berarti di PPAUD Nusa Indah Bumirejo rata-rata anak masih belum bisa bersabar/antri. Tentunya pendidik maupun orangtua hendaknya selalu membiasakan anak untuk belajar antri atau menstimulasi anak untuk menahan diri terhadap kepuasan dan mengendalikan dorongan hati.

Rata-rata persentase empati hampir semua tinggi, yang rendah adalah anak beradaptasi dengan baik dan anak berbagi/ setiakawan. Hal ini menunjukkan bah-wa anak di PPAUD Nusa Indah Bumirejo masih susah untuk beradaptasi di lingkungan baru (malu) dan masih kurang setiakawan/berbagi dengan teman.

Rata-rata persentase membina hubungan dengan orang lain yang tinggi adalah anak ramah dan hormat, sedangkan yang rendah adalah kerja sama orangtua dan pendidik. Dalam hal membina hubungan dengan orang lain, rata-rata anak sudah mampu bersikap ramah dan hormat kepada yang lebih dewasa, namun kerja sama yang dilakukan oleh orangtua dan pendidik masih kurang optimal belum secara intensif.

Kecerdasan emosional atau EQ bukan didasarkan pada kepintaran seorang anak tetapi merupakan karakteristik pribadi 
atau karakter seseorang. Kecerdasan emosional ini lebih penting bagi keberhasilan hidup ketimbang kemampuan intelektual, dengan kata lain EQ tinggi lebih penting dalam pencapaian keberhasilan ketimbang IQ tinggi. Untuk menjadikan anak-anak yang memiliki kecerdasan emosional diperlukan juga orangtua yang telah memiliki EQ dalam mengasuh anak-anaknya. Sesuai yang di tulis oleh Nurkholis (2009) bahwa anak yang memiliki kecerdasan emosi tinggi akan merasa bahagia, percaya diri, popular, serta lebih mampu menguasai gejolak emosi, mengelola stress dan mampu menjalin hubungan baik dengan orang lain.

\section{SIMPULAN DAN SARAN}

\section{Simpulan}

Berdasarkan hsil penelitian ini dapat ditarik kesimpulan sebagai berikut: Pertama, penelitian pengembangan kecerdasan emosi anak di PPAUD Nusa Indah Bumirejo meliputi keterampilan mengenali emosi, mengelola emosi, memotivasi diri, mengenali emosi orang lain/empati dan membina hubungan dengan orang lain. Sampel anak yang diambil dengan kategori status nilai gizi anak baik, sedang, dan rendah. Hasil analisis deskriptif terhadap kecerdasan emosional anak di PPAUD Nusa Indah Bumirejo menunjukkan bahwa semakin baik status nilai gizi anak maka semakin baik pula kecerdasan emosi anak.

Kedua, dari hasil analisis regresi linier diperoleh persamaan: $Y^{\prime}=-126,612+$ $0,845 \mathrm{X}_{1}+0,864 \mathrm{X}_{2}$, dari hasil tersebut dapat meramalkan variabel dependen (kecerdasan emosi anak) yaitu jika pengasuhan pendidik, pengasuhan orangtua ditingkatkan maka kecerdasan emosi anak juga meningkat. Pengasuhan pendidik terhadap kecerdasan emosi anak di PPAUD Nusa Indah Bumirejo berpengaruh signifikan bila dilakukan bersama dengan orangtua, namun tidak berpengaruh jika dilakukan sendiri, ditunjukkan dari hasil uji $\mathrm{t}$ signifikansi sebesar 0,098 > 0,05.

Ketiga, pengasuhan orangtua terhadap kecerdasan emosi anak berpengaruh signifikan. Ditunjukkan dari hasil uji t sebesar $0,000>0,05$. Keempat, kerja sama antara pendidik dan orangtua berpengaruh terhadap pengembangan kecerdasan emosional anak, ditunjukkan sumbangan pengaruh kerja sama antara pendidik dan orangtua secara bersama-sama terhadap kecerdasan emosi anak adalah 73,4\%, dan sisanya $26,6 \%$ merupakan faktor lain yang tidak diteliti.

\section{Saran}

Berdasarkan hasil penelitian maka dapat dikemukakan saran sebagai berikut:

Pertama, dengan diketahui bahwa semakin baik status nilai gizi anak akan meningkatkan kecerdasan emosi anak maka dapat memberi gambaran kepada sekolah/ PAUD (pendidik) dan juga orangtua untuk terus berusaha meningkatkan status nilai gizi anak. Jangan sampai ada anak yang kekurangan gizi. Kedua, dengan adanya pengaruh secara bersama-sama kerja sama antara pengasuhan pendidik dan orangtua terhadap kecerdasan emosi anak maka dapat dijadikan petunjuk bagi sekolah/PAUD untuk berusaha mengupayakan semaksimal mungkin dalam menjalin kerja sama antara pendidik dan kedua orangtua dalam hal kecocokan pengasuhan anak dan menjalin komunikasi yang baik.

Ketiga, dengan adanya pengaruh pengasuhan pendidik bila dilakukan bersama dengan orangtua terhadap kecerdasan emosi anak maka dapat memberi gambaran kepada pendidik untuk selalu berusaha meningkatkan pengetahuan dan keterampilannya dalam mengasuh anak khususnya untuk meningkatkan kecerdasan emosi anak.

Keempat, dengan adanya pengaruh pengasuhan oleh orangtua terhadap kecerdasan emosi anak maka dapat menjadi masukan kepada semua orangtua untuk meningkatkan pengetahuan dan ketrampilan dalam meningkatkan kecerdasan emosi anak (selalu meluangkan waktu untuk anak), orangtua selalu menjaga keharmonisan rumah tangga mereka, membimbing dan memberi teladan yang baik bagi anaknya serta meningkatkan pengetahuan dalam mengasuh anak khususnya dalam hal meningkatkan kecerdasan emosi anak. 
Kelima, kerja sama yang dapat dilakukan oleh pendidik dan orangtua antara lain dengan cara: Menjalin komunikasi yang baik antara pendidik dan orangtua, mengadakan pertemuan rutin antara pendidik dan orangtua (misalnya dalam satu bulan satu kali pertemuan), mengadakan buku penghubung antara pendidik dan orangtua untuk memantau perkembangan anak khususnya kecerdasan emosi anak, mengadakan DDTK (deteksi dini tumbuh kembang) anak dengan melibatkan para orangtua, mengadakan PMT (pemberian makanan tambahan) yang bergizi kepada anak dengan melibatkan orangtua, meningkatkan kualitas kerja sama pendidik dan orangtua dalam menstimulasi kecerdasan emosional anak melalui usaha-usaha yang diarahkan pada pengembangan kecerdasan emosional anak sehingga mampu mengenali perasaan diri sendiri dan perasaan orang lain, mampu memotivasi diri serta mampu mengelola emosi dan perilaku sosial menjadi lebih baik.

Keenam, hendaknya pendidik dan orangtua menguasai tindakan-tindakan prinsip antara lain: Melatih pengendalian diri, mengajarkan pengenalan emosi pada anak, melatih pengelolaan emosi anak, penerapan disiplin dengan konsep empati, mengungkapkan emosi dengan kata-kata, melakukan permainan yang dapat melatih sosial emosi anak, menanggapi perasaan anak, menjadi contoh yang baik, melatih keterampilan emosi.

Ketujuh, dengan diketahui masih ada $26,6 \%$ variabel lain yang berpengaruh terhadap kecerdasan emosi anak, maka perlu diadakan penelitian lebih lanjut.

\section{DAFTAR PUSTAKA}

Depdiknas. (2010). Peraturan Menteri Pendidikan Nasional tentang Standar Pendidikan Anak Usia Dini. Direktorat Jenderal pendidikan Nonformal dan Formal, Kementrian Pendidikan Nasional.

Goleman, D. (200o). Emotional intelligence. kecerdasan emosional. Alih bahasa T. Hermaya. Gramedia Pustaka Utama: Jakarta

Nurkholis.(2009).Meningkatkan kecerdasan emosi dan inteligensi siswa melalui peningkatan kualitas pembelajaran pendidikan jasmani. Jurnal Ilmu Pendidikan. Jilid 16, Nomor 2 Juni 2009 pp. 112-118. Lembaga Pendidikan Tenaga Kependidikan (LPTK) dan Ikatan Sarjana Pendidikan Indonesia (ISPI)

Patmonodewo, S. (2003). Pendidikan anak prasekolah. PT Rineka Cipta: Jakarta

Riduwan. (2007). Skala pengukuran variabelvariabel penelitian. CV Alfabeta: Bandung

Sudjud, A. (1998). Permasalahan dan alternatif solusinya di lembaga prasekolah. FIP IKIP Yogyakarta: Yogyakarta

Yulsyofiend. (2003). Membangun kecerdasan emosional anak usia dini. PEDAGOGI. Jurnal Ilmu Pendidikan. hal 69-76. Fakultas Ilmu Pendidikan Universitas Negeri Padang: Padang

Zuchdi, Darmiyati. (2010). Humanisasi pendidikan menemukan kembali pendidikan yang manusiawi. Bumi Aksara: Jakarta 